Severalls Hospital, Colchester; Dr T. Venkateswarlu, St Anne's Centre, St. Leonards on Sea; Dr G. H. Jones, Tegfan Newydd Day Hospital, Cardiff; Dr N. F. S. Hymas, Addenbrooke's Hospital, Cambridge; Dr R. Thavasothy, Walsgrave Hospital, Coventry; Dr J. M. Annear, Warlingham Park Hospital, Surrey; Dr J. Rao, Weller Wing, Bedford General Hospital

\section{Part II}

Dr I. Treasaden, Ealing Hospital (St Bernard's); DrV.Sharma, Fazakerley Hospital, Liverpool; Dr R. Yuvarajan, Highcroft Hospital, Birmingham;
Dr A. F. Cooper, Leverndale Hospital, Glasgow; Dr M. George, Queen Elizabeth Psychiatric Hospital, Birmingham; Dr L. D. Mulgirigama, Royal Earlswood Hospital, Redhill, Surrey; Professor E. Johnstone, Royal Edinburgh Hospital; Dr C. Davies, Royal United Hospital, Bath; Dr R. Lawrence, South Western Hospital, London SW9; Dr B. Matthews, Springfield Hospital, London SW17; Dr M. Courtney, St James's University Hospital, Leeds; Dr O. Hill, St Luke's Woodside Hospital, London N10; Dr S. Fleminger, The Royal London Hospital; Professor T. J. Fahy, Untversity College Hospital, Galway; Dr L. I. M. Homewood, Wonford House Hospital, Exeter; Dr D. Battin, Worcester Royal Infirmary

\title{
Special Interest Group
}

\section{Proposal for Special Interest Group for Eating Disorders \\ In June 1987 Council approved the establishment of Special Interest Groups.}

Procedure for establishing a Special Interest Group:

(a) Any Member wishing to establish a Special Interest Group shall write to the Registrar with relevant details.

(b) The Registrar shall forward the application to Council.

(c) If Council approves the principle of establishing such a Special Interest Group then it will direct the Registrar to place a notice in the Bulletin, or its equivalent, asking Members of the College to write in support of such a Group and expressing willingness to participate in its activities.

(d) If more than $\mathbf{5 0}$ Members reply to this notice, then Council shall formally approve the establishment of the Special Interest Group.

(e) The administrative support provided will be similar to that enjoyed by College Divisions. It should be noted therefore, that the College will maintain the list of meetings but will not provide staff to attend meetings, organise conferences etc.

In accordance with this procedure, Council has approved the establishment of a Special Interest Group for Eating Disorders. Members are invited to write in support of this Group and express willingness to participate in its activities. Members should write to Mrs Jean Wales at the College. If $\mathbf{5 0}$ Members reply to this notice for each Group, then Council shall formally approve the establishment of this Special Interest Group.

Professor C. Thompson, Registrar 